\title{
中国心理学前沿
}

\section{幽默的情绪调节功能：证据、机 制与研究展望}

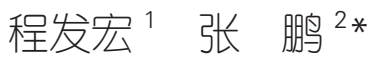 \\ 1. 北京师范大学庆阳附属学校, 庆阳, 745000; \\ 2. 西北民族大学教育科学与技术学院, 兰州, 730070
}

邮箱: pengzhang2@126.com

摘 要: 近年来的研究发现, 幽默具有情绪调节的功能。恰当地使用幽默可以 提升个体的主观幸福感, 管理悲伤情绪以及有效地调节焦虑等负性情绪。幽默 之所以能对情绪进行调节, 可能是由于幽默有效改变了个体对情境的认知评价, 缓解了生活事件给人们所带来的压力, 从而起到对负性情绪调节和对正性情绪 提升的作用。今后的研究应该进一步关注幽默风格在幽默与情绪体验中的调节 作用、心理弹性在幽默与情绪体验中的中介作用和幽默对情绪影响的个体和情 景差异。

关键词: 幽默; 情绪调节; 主观幸福感

收稿日期：2018-12-14; 录用日期：2019-03-16; 发表日期：2019-06-03

文章引用: 程发宏, 张鹏. 幽默的情绪调节功能: 证据、机制与研究展望 [J]. 中国心理学前沿, 2019, 1 ( 4 ): 


\title{
The Emotional Regulation Function of Humor: Evidence, Mechanism and Prospect
}

\author{
Fahong Cheng $^{1} \quad$ Peng Zhang ${ }^{2} *$ \\ 1.Qingyang School Attached to Beijing Normal University, Qinyang 745000; \\ 2. College of Educational Science and Technology Northwest University for \\ Nationalities, Lanzhou 730030
}

Abstract: Recent researches showed that humor possesses the function of emotional regulation.Individual's subjective well-being, the management of sadness as well as the effectiveness of adjusting anxiety can be enhanced by using humor properly.The reason of humor to emotional regulation can be contributed to changing effectively the individual's perception of situation regulation and alleviating the pressure of life events by humor.That can achieve the goal of regulation to negative emotion and enhancement to positive emotion.Future research should further focus on the moderating effect of humorous style in humor and emotional experience, the mediate function of resilience in humor and emotional experience as we as the individual's difference of humor to emotional influence.

Key words: Humor; Emotional regulation; Subjective well-being; Sadness; Anxiety

Received: 2018-12-14; Accepted: 2019-03-16; Published: 2019-06-03

Copyright (c) 2019 by author(s) and SciScan Publishing Limited.

This article is licensed under a Creative Commons Attribution-NonCommercial 4.0 International License.

https://creativecommons.org/licenses/by-nc/4.0/ 


\section{1 引言}

幽默是一个具有多面性和复杂性的文化现象 $[1]$ ，是指个体凭借言语的趣 味性和滑稽性，引起他人发笑等情感快速反应的一种行为。幽默的发生包含四 个基本的成分：使用幽默时的具体情境，感知到幽默的个体对幽默的理解和加 工的过程，在幽默加工过程中所伴随的内在情绪体验以及对幽默加工后的外在 情绪表现 [2]。研究认为, 有四种基本的幽默风格 [3]：友好幽默（Affiliative Humor），即个体通过分享一些有趣的故事或笑话，来使自己和他人开心，同时 使彼此的关系更加亲近 [4] [5]；自我提升幽默（Self-enhancing Humor）， 指个体采用幽默的视角，对生活保持一种积极乐观的态度 [6]; 挑畔型幽默 (Aggressive Humor)，指个体通过讽刺、嘲笑和贬低他人以达到幽默的目的 [7]; 自我贬低幽默（Self-defeating Humor），指个体以损害自尊为代价，通过讲述关 于自己的趣事来娱乐他人的一种幽默风格 [8]。研究发现，积极的幽默风格 (友 好型幽默和自我提升型幽默)和消极的幽默风格 (挑畔型幽默和自我贬低型幽默) 对情绪体验的影响不同, 高水平的积极的幽默通常与较低的抑郁水平和较高的 自尊相关 $[9][10 ］[11][12 ］$ 。相反，高水平的消极的幽默通常与更高的 抑郁水平和较低的自尊相关 [2] [ 10 ] [ 12］［13］。同时，友好幽默在增进 人际关系 [14］［15］、解决情侣在约会中产生的矛盾 ［14］［16］以及在自尊、 创造性的应对能力和自我判断能力 [17]、乐观 [18]等方面起着积极的促进作用, 而使用挑衅型幽默则不利于增进人际关系与情绪调节［19］［20］。积极幽默 风格不但具有提升正性情绪体验的作用，而且还可以缓解社会紧张局势 [19] [21]。虽然消极的幽默也被认为具有情绪调节的功能, 但是它和积极幽默相比, 产生的积极情绪体验却很少 [22], 此外, 研究表明, 这四种幽默风格具有跨 文化的一致性 $[11][12][13]$ 。

近年来的研究发现, 幽默不仅可以使得他人产生愉悦的情绪体验, 而且还 
能够有效地调节个体自身的情绪, 增强个体的主观幸福感和生活满意度 [ 1 ] 22 。 恰当的使用幽默可以有效地调节个体的负性情绪, 增强正性情绪体验 [23][24]。 当人们观看一部具有紧张气氛的电影时，创设一个幽默的故事会比创设一个严 肃的故事更能缓解人们的心理压力，减少抑郁的情绪以及降低负面影响 [22］； 如第二次世界大战集中营中的幸存者和战俘，通过使用幽默来缓解痛苦和降低 负性情绪 [25]，即使在死亡来临之际，幽默同样可以使大屠杀中的风犯缓解 负性情绪 [26]。

本文将从幽默对情绪影响的证据，幽默调节情绪的内在机制等方面对幽默 的情绪调节功能进行阐述，以期为之后该领域的研究提供新的视角。

\section{2 幽默对情绪影响的证据}

\section{1 幽默对主观幸福感的影响}

大量的研究发现，幽默对个体主观幸福感的提升具有促进作用 [3] [ 26] [27] [28］［29］［30］。Cann 和 Collette 以大学生为研究对象，对幽默感和主观幸 福感的关系进行研究表明，幽默对个体幸福感的保持具有促进作用，尤其是积 极幽默（友好幽默和自我提升的幽默），积极幽默不仅有助于提升个体整体幸 福感，而且有助于提高个体在所从事活动中的主观幸福感的感受 $[20 ］[28]$ 。 Leist 和 Muller (2013) 等人的研究也得出了相同的结论, 即积极幽默和主观幸 福感之间呈正相关，消极幽默与主观幸福感呈显著负相关。同时，积极幽默有 助于改善人际关系、提升自我，而消极幽默则与之相反 [3]。此外，在企业管 理中的研究也发现，领导的幽默风格对员工主观幸福感有重要影响，领导使用 积极幽默与员工的主观幸福感呈正相关，使用消极幽默则呈负相关 [15]；国 内学者陈世民等人以中国大学生为被试，采用幽默风格问卷中的自我提升幽默 维度，主观幸福感量表中的积极情绪和消极情绪维度，多维领悟社会支持量表 和生活满意度量表探讨了自我提升幽默与生活满意度之间的关系，结果显示， 自我提升幽默通过情绪幸福和社会支持两个中介变量提升了个体的生活满意度 [31］。另外，幽默对主观幸福感的提升在恋爱关系中也得到了充分的体现 [16 
[32］，情侣双方使用积极幽默有利于对问题的思考、冲突的解决和主观幸福 感的提升，消极幽默则与之相反，并且幽默也被评为是最有效的情侣吸引策略 [16]。从进化的角度， $\mathrm{Li}$ 等人探讨了幽默是性别选择还是兴趣指向的结果。 结果发现, 当面对具有吸引力的个体时, 男性和女性都会使用积极幽默对彼此 做出积极的反应，并使彼此的关系更加亲密，这一结果不仅支持了幽默是表达 浪漫的一种手段，而且证明了幽默是调节社会关系的一种有效策略 [33］。

\section{2 幽默对悲伤的影响}

研究发现，幽默对个体的悲伤情绪具有一定的缓解作用 [34］［35］［36］。 例如，战俘通过使用幽默来应对他们所面临的困境，从而使他们的悲伤等负性 情绪水平降低 $[37]$; 在洪涝 [36 ]、人质劫持 $[38$ ] 等宭迫情境下，使用幽 默会有效地管理个体的悲伤等负性情绪。根据 Moran 和 Massam 的研究, 在关键 时刻犯人使用幽默能够更好地应对当时的环境，采取嘲笑对方的方式可以使他 们的关系更加亲近，最重要的是，使用幽默可以对他们内心的悲伤情绪起到调 节作用 [39］。Booth-Butterfield 等人对幽默在个体丧失亲人时的情绪管理中的 作用进行了研究。研究采用幽默倾向量表、幽默和死亡应对测验、应对效能量 表和悲伤症状测验对经历过亲人和同伴死亡的 484 名被试进行调查。结果表明， 在亲人和同伴离世时，使用幽默有助于调节个体的悲伤情绪，促进个体与他人 的交流。在面对亲人死亡时，幽默有效地减少了个体不良的身体和负性情绪症 状的发生。当个体处于悲伤情境之中时，积极幽默能够对个体的悲伤情绪和身 体症状起到正向预测的作用, 消极幽默( 挑畔幽默和自我贬低幽默) 则相反 [ 36 ]; Lund 等人对丧偶后个体日常生活中幽默所起的作用进行的研究显示，使用积极 幽默可以使失去配偶后的个体体验到更少的悲伤等负性情绪和感受到更多的快 乐 $[35]$ 。

\section{3 幽默对焦虑的影响}

幽默对个体的焦虑情绪具有调节作用 [3]［9］［40］［41］。研究发现， 幽默感水平高的个体比幽默感水平低的个体在日常生活中会体验到更少的焦虑 
情绪 [42］，幽默水平高的个体能够更好地应对压力，同时表现出更少的焦虑 情绪 $[43]$ 。

Scott 等人将幽默作为认知行为疗法的一项技术，对幽默在老年人的抑郁和 焦虑中所起的作用进行了探讨，研究发现，幽默对老年人的人际关系、抑郁和 焦虑等负性情绪体验具有强有效的调节作用 [41］；Richman（1998）对幽默在 老年人死亡焦虑和伴随衰老出现的心理问题的关系中的作用进行的研究表明， 使用幽默有助于减少老年人生活中出现的抑郁焦虑等负性情绪体验，应对衰老 出现的心理问题, 提升他们的生活满意度。Kuiper, Aiken 和 Pound 对幽默的使用、 社会评论和社交焦虑之间的关系的研究表明，使用积极幽默时社会评论更加积 极，个体几乎没有社交焦虑，而使用消极幽默时社会评论更加消极，且个体在 一定程度上存在社交焦虑 [40] ; 在大学生中的研究也发现，偏执的不确定性 抑制积极幽默风格的使用，增加消极幽默风格的使用，但总体上幽默对个体的 担心和焦虑具有调节作用 $[9]$ 。

Kuiper、Kirsh 和 Leite 对幽默的内因理论与幽默评论之间的关系进行了研究， 结果表明，积极幽默是个体使用频率最高的幽默类型，并且使用积极幽默会对 彼此产生一种舒服的感觉，而消极幽默使用的频率最低，使用该类型的幽默会 让人产生厌恶的感觉 [19]。研究发现, 不同的幽默风格与焦虑有着不同的关 系 [ 17 ] [44]。Martin（2010）认为, 积极幽默对焦虑等负性情绪具有调节作用, 消极幽默则对负性情绪的调节作用相对较差，甚至有相反的作用。友好幽默风 格与较低的焦虑有关，可以改善人际关系 [9] [17］。自我提升幽默可以减少 自身焦虑体验［17］［21］。相反，自我贬低型幽默风格作为一种消极的幽默方 式，与个体更高水平的焦虑有关 [3]。国内学者陈国海和加拿大学者 Martin 以 两国大学生为被试，采用幽默风格量表症状自评量表对大学生的幽默风格与精 神健康关系进行了初步研究，结果显示，亲和型幽默、自强型幽默得分与症状 自评量表的子量表以及总体症状指数得分全部呈负相关，而嘲讽型幽默和自贬 型幽默得分与症状自评量表的子量表以及总体症状指数得分全部呈正相关，因 此得出结论, 亲和型和自强型幽默有益于精神健康, 嘲讽型和自贬型幽默有害 于精神健康，并且中国人与加拿大人在幽默风格、幽默对精神健康起作用的方 
式上存在一定的文化差异 $[13]$ 。

此外，研究表明，幽默风格对孤独感有一定的调节作用，积极幽默与孤独 呈显著负相关，而消极幽默与孤独没有关系 [34]; 而且，幽默作为应对老龄 化的一种策略，可以减少老年人的疾病和健康问题症状，促进人际关系更加亲 密和提升生活满意度以及延长老年人的寿命 $[45]$ 。

\section{3 幽默调节情绪的内在机制}

如前所述，幽默可以提升个体的主观幸福感，有效地缓解悲伤和焦虑等负 性情绪。幽默之所以能对情绪进行调节，可能是因为幽默有效地改变了个体对 情境的认知评价, 缓解了生活事件给个体带来的压力, 从而达到对负性情绪的 调节和对正性情绪提升的目的。

幽默被看作个体的一种适应性特征, 被认为是压力的缓冲器 $[28][43][46][47$ [48］[49][50 ]。研究显示, 积极幽默对个体的压力缓解具有促进的作用 [ 43]; 积极幽默与压力等心理健康指标呈负相关，消极幽默则相反 [28]，幽默对老 年人的压力管理也同样有效，被看作提高老年人的生活质量和协助管理压力的 一种手段 [51]。此外, 幽默在司法人员办案过程中所起的作用研究表明, 幽 默有助于减少他们在完成工作任务时的压力, 调节他们的负性情绪 [50 ] ; 在 为艾滋病提供服务的群体上的研究也表明,积极幽默有助于缓解他们的工作压力、 减少紧张和增强斗志 [52]；同时，在职场中，幽默有助于缓解个体在职场中的 压力, 并可以为职场增添乐趣 [48]; 在组织中, 幽默作为一种多功能的管理 工具，管理者使用幽默可以缓解自身和员工的压力、提高领导能力、增强团队 凝聚力和创造力以及有助于构建组织文化 [47], 有助于组织内部进行有效沟通、 形成共同的发展目标，有效地缓解组织内部成员的压力等负性情绪; 幽默在中国教 师应对压力过程中的作用的研究表明，中国教师使用幽默应对压力的频率低于其他 应对方式，中国教师更多的是把幽默作为一种逃避或回避问题的应对策略 [53 ]。

那么, 个体是如何通过幽默来缓解压力以及调节自身情绪的呢? 研究发现, 幽默可以改变个体对威胁和紧张情境的认知评价, 以达到应对压力的目的 [3]。 Martin 和 Lefcourt [54] 认为, 幽默可以为个体提供一个看待自己所面临问题的 
新视角, 并且能够使个体与问题保持适当的心理距离，从而起到缓解压力的作 用。Samson 和 Gross 从情绪调节的角度探讨了幽默的两面性, 研究中提出幽默 凭借自身言语的趣味性和滑稽性的特质，面对压力情景时，可以迅速的转移个 体的注意资源，缓解个体的压力，重新审视问题，从而可以达到调节情绪的目 的 [1] ; 幽默应对策略在情绪的改善过程中起着重要的作用，在幽默应对策略 对情绪的影响研究中，研究者让被试采用幽默的方式看待和评价消极刺激，以 观测幽默对负性情绪的调节作用。例如在观看一张男性额头缝针的图片时，被 试需要使用幽默方式去评价和看待这张图片：现在他有一件漂亮的万圣节的服 装。结果表明，无论是在短时间还是长时期内，幽默应对策略在降低负性情绪 和提升正性情绪方面都更加的有效 [55]。幽默的情感动机理论认为，在具体 情景中，由于幽默唤醒了个体对事件重新的认知，从而缓解了生活事件给个体 带来的压力，继而间接地调节了个体的负性情绪体验，提升了个体的正性情绪 体验 $[2]$ 。幽默的认知理论认为幽默本身就带有不协调因素，而这些不协调因 素属于个体认知的核心成分, 由于不协调因素的特点与个体原有的认知存在冲 突，进而会为个体思考问题提供一个全新的视角，使个体对事件进行重新的认 知 $[2]$ 。

\section{4 研究展望}

\section{1 幽默风格在幽默与情绪体验中的调节作用}

如前所述，幽默的四种风格：友好幽默风格、自我提升幽默风格、挑衅型 幽默风格和自我贬低幽默风格具有跨文化的一致性 $[11 ］ ［ 12 ］ ［ 13 ］ ［ 56]$ 。 积极的幽默风格（友好型幽默和自我提升型幽默）和消极的幽默风格（挑衅型 幽默和自我贬低型幽默）对情绪体验的影响不同，同时，不同的幽默风格在幽 默与情绪体验过程中起着不同的调节作用，但是，幽默风格在幽默和情绪体验 过程中具体起着怎样的调节作用，尚不得而知。因此，今后的研究应关注幽默 风格在幽默与情绪体验中的调节作用，例如积极幽默和消极幽默对主观幸福感 的影响方式和途径，挑衅型幽默和自我贬低幽默对负性情绪的影响等。 


\section{2 心理弹性在幽默与情绪体验中的中介作用}

心理弹性是个体相对稳定的人格特质，具有使个体免受生活逆境和负性情绪 影响的功能 [57 ], 能够引导个体最终走出逆境 [58 ]。当个体面对生活压力的 负面影响时，使用较高水平幽默应对的个体比使用低水平幽默应对的个体心理弹 性水平更高。当负面生活事件的数量不断增加时，心理弹性水平高的个体表示很 少或几乎没有增加负面情绪体验。相反，当负性生活事件的数量不断增加时，心 理弹性水平低的个体的负性情绪体验会明显增加 [59]。同时, 研究表明, 幽 默有助于增强个体的心理弹性［28］［60］［61］［62］、提升个体的正性情绪、 缓解个体的负性情绪体验 [62]。综上可以发现，幽默有可能通过提升个体的 心理弹性水平来调节个体的情绪, 因此, 未来的研究应进一步探讨心理弹性水 平在幽默与情绪调节中的中介作用。

\section{3 幽默对情绪影响的个体差异}

研究发现，幽默的使用存在性别差异。如 Marttin 等人（2003）的研究发现, 男性在幽默风格各分量表上的得分均高于女性; 在面对丧亲之痛时, 男性在幽 默取向、应对效能和具体的使用幽默来交流方面得分高于女性，在生理和心理 症状上, 男性得分显著低于女性 [36] ; 国内陈国海等人（2005）研究发现, 男性比女性会更多地使用幽默应对 [63]。同时，幽默的使用也与个体的人格 特质有关，研究发现，友好幽默风格和自我提升幽默风格与外向性、开放性和 女性气质呈显著正相关, 与神经质、宜人性、责任心和消极的女性气质呈负相关; 而挑畔型幽默和自我贬低幽默与宜人性、责任心和女性气质呈显著负相关，与 神经质和消极的男性气质呈正相关 [3] [64]。Veselka 等人（2008）的研究也 表明，友好幽默、自我提升幽默风格与外向性、宜人性和经验的开放性呈正相关， 与神经质呈负相关; 而挑畔型幽默、自我贬低幽默与外向性和神经质呈正相关, 与责任心、宜人性和诚实一谦逊呈负相关。因此, 幽默对情绪的影响受到个体 差异的影响, 今后的研究应关注幽默对情绪调节的个体差异, 如研究性别、人 格特质在幽默使用与情绪体验中的调节作用，以及二者之间的交互作用等。 


\section{参考文献}

[ 1 ] Samson A C, Gross J J. The dark and light sides of humor: An emotion regulation perspective [ J ] . The dark and light sides of positive emotion, 2014: 169-182. https://doi.org/10.1093/acprof:oso/9780199926725.003.0010

[2 ] Martin R A. The psychology of humor: An integrative approach [ M ] . Cambridge: Academic press, 2010.

[3] Martin R A, Puhlik-Doris P, Larsen G, et al. Individual differences in uses of humor and their relation to psychological well-being: Development of the Humor Styles Questionnaire [ J ] . Journal of research in personality, 2003, 37(1). https://doi.org/10.1016/S0092-6566(02)00534-2

[4 ] Lefcourt H M. Humor: The psychology of living buoyantly [ M ] . Berlin: Springer Science \& Business Media, 2001. https://doi.org/10.1007/978-1-4615-4287-2

[ 5 ] Vaillant G E. Adaptive mental mechanisms: Their role in a positive psychology[ J ]. American psychologist, 2000, 55(1).

https://doi.org/10.1037//0003-066X.55.1.89

[6] Martin R A, Kuiper N A, Olinger L J, et al. Humor, coping with stress, selfconcept, and psychological well-being [ J ] . Humor, 1993, (89-103). https://doi.org/10.1515/humr.1993.6.1.89

[ 7 ] Zillmann D, Rockwell S, Schweitzer K, et al. Does humor facilitate coping with physical discomfort? [ J ] . Motivation and Emotion, 1993, 17(1). https://doi.org/10.1007/BF00995204

[ 8 ] Long D L, Graesser A C. Wit and humor in discourse processing [ J ] . Discourse processes, 1988, 11(1). https://doi.org/10.1080/01638538809544690

[9] Kuiper N A, Klein D, Vertes J, et al. Humor Styles and the Intolerance of Uncertainty Model of Generalized Anxiety [ J ] . Europe's Journal of Psychology, 2014, 10(3). https://doi.org/10.5964/ejop.v10i3.752

[10 ] Kalliny M, Cruthirds K W, Minor M S. Differences between American, Egyptian 
and Lebanese Humor Styles Implications for International Management [ J ] . International Journal of Cross Cultural Management, 2006, 6(1). https://doi.org/10.1177/1470595806062354

[11] Taher D, Kazarian S S, Martin R A. Validation of the Arabic Humor Styles Questionnaire in a community sample of Lebanese in Lebanon $[\mathrm{J}]$. Journal of Cross-Cultural Psychology, 2008, 39(5).

https://doi.org/10.1177/0022022108321177

[12 ] Vernon P A, Martin R A, Schermer J A, et al. A behavioral genetic investigation of humor styles and their correlations with the Big-5 personality dimensions $[\mathrm{J}]$. Personality and Individual Differences, 2008, 44(5).

https://doi.org/10.1016/j.paid.2007.11.003

[13] 陈国海.大学生幽默风格与精神健康关系的初步研究 [J ] . 心理学, 2007, $30(1)$.

[14 ] Campbell L, Martin R A, Ward J R. An observational study of humor use while resolving conflict in dating couples [ J ] . Personal Relationships, 2008, 15(1). https://doi.org/10.1111/j.1475-6811.2007.00183.x

[ 15 ] Unal Z M. Influence of leaders' humor styles on the employees' job related affective well-being [ J ] . International Journal of Academic Research in Accounting, Finance and Management Sciences, 2014, 4(1).

https://doi.org/10.6007/IJARAFMS/v4-i1/585

[ 16] CaLimpbell L, Moroz S. Humour Use Between Spouses and Positive and Negative Interpersonal Behaviours During Conflict [ J ] . Europe's Journal of Psychology, 2014, 10(3). https://doi.org/10.5964/ejop.v10i3.763

[ 17 ] Kuiper N A, Grimshaw M, Leite C, et al. Humor is not always the best medicine: Specific components of sense of humor and psychological well-being $[\mathrm{J}]$. Humor: International Journal of Humor Research, 2004, 17(1 /2). https://doi.org/10.1515/humr.2004.002

[ 18 ] Yue X D, Hao X I A, Goldman G L. Humor Styles, Dispositional Optimism, and 
Mental Health Among Undergraduates in Hong Kong and China [ J ] . Journal of Psychology in Chinese Societies, 2010, 11(2).

[19] Kuiper N A, Kirsh G A, Leite C. Reactions to humorous comments and implicit theories of humor styles [ J ] . Europe's Journal of Psychology, 2010, 6(3). https://doi.org/10.5964/ejop.v6i3.215

[ 20 ] Ford T E, McCreight K A, Richardson K. Affective Style, Humor Styles and Happiness [ J ] . Europe's Journal of Psychology, 2014, 10(3). https://doi.org/10.5964/ejop.v10i3.766

[21] Kuiper N A, Leite C. Personality impressions associated with four distinct humor styles [ J ] . Scandinavian Journal of Psychology, 2010, 51(2). https://doi.org/10.1111/j.1467-9450.2009.00734.x

[22] Samson A C, Gross J J. Humour as emotion regulation: The differential consequences of negative versus positive humour $[\mathrm{J}]$. Cognition \& emotion, 2012, 26(2). https://doi.org/10.1080/02699931.2011.585069

[23 ] Ong A D, Bergeman C S, Bisconti T L, et al. Psychological resilience, positive emotions, and successful adaptation to stress in later life $[\mathrm{J}]$. Journal of personality and social psychology, 2006, 91(4).

https://doi.org/10.1037/0022-3514.91.4.730

[ 24 ] Geisler F C M, Weber H. Harm that does not hurt: Humour in coping with selfthreat $[\mathrm{J}]$. Motivation and Emotion, 2010, 34(4). https://doi.org/10.1007/s11031-010-9185-6

[ 25 ] Henman L D. Humor as a coping mechanism: Lessons from POWs[J ] . Humor International Journal of Humor Research, 2001, 14(1): 83-94. https://doi.org/10.1515/humr.14.1.83

[ 26 ] Frankl V E, Allport G W. El hombre en busca de sentido [ M ] . Herder, 2004.

[27 ] Leist A K, M ü ller D. Humor types show different patterns of self-regulation, self-esteem, and well-being [ J ] . Journal of Happiness Studies, 2013, 14(2). https://doi.org/10.1007/s10902-012-9342-6 
[28 ] Cann A, Collette C. Sense of Humor, Stable Affect, and Psychological WellBeing [ J ] . Europe's Journal of Psychology, 2014, 10(3). https://doi.org/10.5964/ejop.v10i3.746

[29] Maiolino N B, Kuiper N A. Integrating humor and positive psychology approaches to psychological well-being [ J ] . Europe's Journal of Psychology, 2014, 10(3). https://doi.org/10.5964/ejop.v10i3.753

[ 30 ] Cann A, Kuiper N A. Research on the Role of Humor in Well-Being and Health[ J ]. Europe's Journal of Psychology, 2014, 10(3).

https://doi.org/10.5964/ejop.v10i3.818

[31] 陈世民, 方杰, 高树玲, 等. 自我提升幽默与生活满意度的关系 : 情绪幸福 和社会支持的链式中介模型 $[J]$. 心理科学, 2014, 2(21).

[ 32 ] Bressler E R, Balshine S. The influence of humor on desirability [ J ] . Evolution and Human Behavior, 2006, 27(1).

https://doi.org/10.1016/j.evolhumbehav.2005.06.002

[33 ] Li N P, Griskevicius V, Durante K M, et al. An evolutionary perspective on humor: sexual selection or interest indication?[J]. Personality and Social Psychology Bulletin, 2009. https://doi.org/10.1177/0146167209334786

[ 34 ] Cecen A R. Humor styles in predicting loneliness among Turkish university students [ J ] . Social Behavior and Personality: an international journal, 2007, 35(6). https://doi.org/10.2224/sbp.2007.35.6.835

[ 35 ] Lund D, Caserta M, Utz R, et al. Experiences and early coping of bereaved spouses/partners in an intervention based on the dual process model (DPM) $[\mathrm{J}]$. OMEGA-Journal of Death and Dying, 2010, 61(4).

https://doi.org/10.2190/OM.61.4.c

[ 36 ] Booth-Butterfield M, Wanzer M B, Weil N, et al. Communication of Humor During Bereavement: Intrapersonal and Interpersonal Emotion Management Strategies [ J ] . Communication Quarterly, 2014, 62(4). https://doi.org/10.1080/01463373.2014.922487 
[ 37 ] Coffee G. Beyond Survival: Building on the Hard Times-A POW's Inspiring Story [ M ] . AudioInk Publishing, 2013.

[ 38 ] McGhee P E. Health, healing and the amuse system: Humor as survival training [ M ] . Kendall/Hunt Pub., 1999.

[39 ] Moran C, Massam M. An evaluation of humour in emergency work [ J ] . The Australasian Journal of Disaster andTrauma Studies, 1997, 3(1).

[ 40 ] Kuiper N A, Aiken A, Pound M S. Humor use, reactions to social comments, and social anxiety [ J ] . HUMOR, 2014, 27(3). https://doi.org/10.1515/humor-2014-0072

[41] Scott C V, Hyer L A, McKenzie L C. The Healing Power of Laughter: The Applicability of Humor as a Psychotherapy Technique With Depressed and Anxious Older Adults [ J ] . Social Work in Mental Health, 2015, 13(1). https://doi.org/10.1080/15332985.2014.972493

[ 42 ] Abel M H. Humor, stress, and coping strategies [ J ] . Humor-International Journal of Humor Research, 2002, 15(4). https://doi.org/10.1515/ humr.15.4.365

[ 43 ] Abel M H, Maxwell D. Humor and affective consequences of a stressful task [ J ] . Journal of Social and Clinical Psychology, 2002, 21(2). https://doi.org/10.1521/jscp.21.2.165.22516

[ 44 ] Fitts S D, Sebby R A, Zlokovich M S. Humor styles as mediators of the shynessloneliness relationship [ J ] . North American Journal of Psychology, 2009, 11(2).

[ 45 ] Berk R A. The greatest veneration: Humor as a coping strategy for the challenges of aging [ J ] . Social Work in Mental Health, 2015, 13(1). https://doi.org/10.1080/15332985.2014.890152

[ 46 ] Adamle K N, Ludwick R. Humor in hospice care: who, where, and how much?[ J ]. American Journal of Hospice and Palliative Medicine, 2005, 22(4). https://doi.org/10.1177/104990910502200410

[47 ] Romero E J, Cruthirds K W. The use of humor in the workplace [ J ]. The 
Academy of Management Perspectives, 2006, 20(2).

https://doi.org/10.5465/amp.2006.20591005

[ 48 ] Plester B. Crossing the line: Boundaries of workplace humour and fun [ J ] . Employee relations, 2009, 31(6). https://doi.org/10.1108/01425450910991749

[49] Romero E, Pescosolido A. Humor and group effectiveness [ J ]. Human Relations, 2008, 61(3). https://doi.org/10.1177/0018726708088999

[ 50 ] Vivona B D. Humor functions within crime scene investigations: group dynamics, stress, and the negotiation of emotions [ J ] . Police quarterly, 2014, 17(2). https://doi.org/10.1177/1098611114531418

[51 ] Shammi P, Stuss D T. The effects of normal aging on humor appreciation $[\mathrm{J}]$. Journal of the International Neuropsychological Society, 2003, 9(6). https://doi.org/10.1017/S135561770396005X

[52 ] Kosenko K A, Rintamaki L S. Forms, functions, and foibles of humor used in AIDS service organizations $[\mathrm{J}]$. Journal of the Association of Nurses in AIDS Care, 2010, 21(1). https://doi.org/10.1016/j.jana.2009.08.001

[ 53 ] Wu J, Chan R M C. Chinese teachers' use of humour in coping with stress [ J ] . International Journal of Psychology, 2013, 48(6). https://doi.org/10.1080/00207594.2012.734623

[ 54 ] Martin R A, Lefcourt H M. Situational humor response questionnaire: Quantitative measure of sense of humor $[\mathrm{J}]$. Journal of personality and social psychology, 1984, 47(1). https://doi.org/10.1037//0022-3514.47.1.145

[55 ] Samson A C, Glassco A L, Lee I A, et al. Humorous Coping and Serious Reappraisal: Short-Term and Longer-Term Effects [ J ] . Europe's Journal of Psychology, 2014, 10(3). https://doi.org/10.5964/ejop.v10i3.730

[56 ] Vernon P A, Martin R A, Schermer J A, et al. Genetic and environmental contributions to humor styles: A replication study $[\mathrm{J}]$. Twin Research and Human Genetics, 2008, 11(1). https://doi.org/10.1375/twin.11.1.44

[57 ] Windle G. What is resilience? A review and concept analysis $[\mathrm{J}]$. Reviews in 
Clinical Gerontology, 2011, 21(2). https://doi.org/10.1017/S0959259810000420

[ 58 ] Veselka L, Schermer J A, Martin R A, et al. Relations between humor styles and the Dark Triad traits of personality [ J ] . Personality and Individual Differences, 2010, 48(6). https://doi.org/10.1016/j.paid.2010.01.017

[59] Martin R A, Lefcourt H M. Sense of humor as a moderator of the relation between stressors and moods $[\mathrm{J}]$. Journal of personality and social psychology, 1983, 45(6). https://doi.org/10.1037//0022-3514.45.6.1313

[60 ] Peterson C, Ruch W, Beermann U, et al. Strengths of character, orientations to happiness, and life satisfaction [ J ] . The Journal of Positive Psychology, 2007, 2(3). https://doi.org/10.1080/17439760701228938

[61 ] Kuiper N A. Humor and resiliency: Towards a process model of coping and growth [ J ] . Europe's Journal of Psychology, 2012, 8(3). https://doi.org/10.5964/ejop.v8i3.464

[62 ] Fredrickson B L. Positive emotions broaden and build [ J ] . Advances in experimental social psychology, 2013,47(1-53).

https://doi.org/10.1016/B978-0-12-407236-7.00001-2

[63] 陈国海. 应对幽默量表在 354 名中国大学生中的初步测试 [ J ] . 中国心理 卫生杂志 , 2005, 19(5).

[64 ] Mendiburo - Seguel A, P á ez D, Mart í nez - S á nchez F. Humor styles and personality: A meta - analysis of the relation between humor styles and the Big Five personality traits $[\mathrm{J}]$. Scandinavian journal of psychology, 2015, 56(3). https://doi.org/10.1111/sjop.12209 